\title{
TOWARDS A HALF-BRED POETICS: THE ROLE OF DRAMATIC IRONY IN THE SHORT STORIES OF THE CHICANO BORDERLANDS ${ }^{1}$
}

\author{
Carolina Fernández Rodríguez ${ }^{2}$
}

\begin{abstract}
Diasporic writing has given rise to what some critics have called "Half-bred poetics" or "Hyphen poetics", among other terms, and it is in the context of this poetics that diasporic writing can be best understood. Most accounts of the aesthetic features that characterise diasporic literatures stop at the analysis of what is probably its most salient characteristic, that is, the issue of interlingualism and language variance. However, in this paper I will analyse the recurrent use of dramatic irony in several Chicano short stories in order to explain the reasons why this type of irony is so convenient for diasporic prose writers.
\end{abstract}

Key words: Half-bred poetics, Chicano Literature, short story, dramatic irony.

Resumen: La literatura diaspórica ha dado lugar a lo que algunos críticos han llamado "poéticas mestizas" o "poéticas con guión", entre otros términos, y es en ese contexto crítico en el que mejor puede apreciarse la riqueza de la escritura diaspórica. La mayoría de los estudios que explican cuáles son los rasgos estéticos de las literaturas diaspóricas se centran únicamente sobre el que probablemente sea su rasgo más característico, es decir, el del uso del interlingualismo y la variación lingüística. Sin embargo, en este artículo el objeto de estudio será el uso de la ironía dramática en varios relatos breves de autores Chicanos, con el fin de explicar las razones por las que este tipo de ironía es muy apropiado para los escritores diaspóricos en prosa.

Palabras clave: Poéticas mestizas, literatura chicana, relato breve, ironía dramática.

In order to prepare the ground for what will be my purpose later on, I should start by bringing up one of Gloria Anzaldúa's definitions of the Chicano borderlands: "The U.S.Mexican border es una herida abierta where the Third World grates against the first and bleeds. And before a scab forms it hemorrhages again, the lifeblood of two worlds merging to form a third country -a border culture" (3). A few elements are worth pointing out here. First, the Chicano borderlands is a world made up of at least two other conflicting worlds, the Mexican and the American, the merging of which is the result of a difficult and painful process metaphorically represented by the semantic field of the wound. Secondly, their transformation into that "third country" is a paradoxical formation (the scab is formed only after one more shed of blood), the embodiment of multiple discrepancies: between the tenets of each of the two original worlds, and also between those original worlds and

Fecha de recepción: mayo 2007.

Fecha de aceptación y versión final: julio 2007.

2 Lecturer, Departamento de Filología Anglogermánica y Francesa, Universidad de Oviedo; $₫$ carol@uniovi.es. 
the third one. Finally, it is an ironical genesis where "there is an incongruity between what is expected to happen and what actually happens" ("Irony", Bedford/St. Martin's): out of an open wound may come something good; out of two hurt beings a healthy new one may be formed.

The literature produced in the Chicano borderlands, as well as in many other border cultures, is likewise the outcome of conflicting worldviews and literary traditions. Similarly, the poetic theory that corresponds to it is an amalgam of two or more systems; yet, it is idiosyncratic and autonomous: it constitutes a world of its own, a "third" sphere which has become independent from the original poetics out of which it got shape. Critics generally refer to these new bodies of poetic theory as "half-bred" or "hyphen" poetics (see, for example, Wah 1997). The phrase "half-bred" puts emphasis on the multi-racial and/or multicultural nature of the writers who work within border cultures, as well as on the texts that are produced in those contexts in an attempt to synchronize two or more cultures. On the other hand, the term "hyphen" allows critics to reflect on the paradoxical nature of border cultures, since the hyphen represents "that marked (or unmarked) space that both binds and divides" (Wah 1996: 60). In fact, when analysing a text produced in any borderlands, critics often foreground the strategies that allow such a text to represent what Fred Wah has called a "synchronous foreignicity", that is, the elements that allow it "to remain within an ambivalence without succumbing to the pull of any single culture" (62).

Of all the elements that make up a border text, it is the linguistic form that has more frequently caught the attention of literary critics and, in general, of anyone interested in border poetics. In particular, those who have ventured into this territory have focused on what is generally known as "code-switching". Fred Wah, for example, has selected this feature as the most salient characteristic of the border text, and he describes it as "the movement between two languages, usually the intentional insertion into the master language of foreign or colloquial terms and phrases that represent the power to own but not be owned by the dominant language" (62).

The processes by means of which border language appropriates the master language is also considered as the key to understand Chicano literature (or, more precisely, Chicano poetry) in Alfred Arteaga's Chicano Poetics. Heterotexts and Hybridities (1997). Arteaga begins his analysis of Chicano poetics by referring to "difrasismo", a trope which is characteristic of Nahuatl poetry and a general feature of Nahuatl language and thought. He describes this rhetorical figure as "the means of representing something in the coupling of two elements" (6), an example of which would be Nahuatl phrase for "poetry": "in xóchtl in cuicatl", or "flower and song". According to Arteaga, Nahuatl tendency to bring together different constituents is likewise present in hybrid subjects, in general, and in the Chicano subject, in particular: "hybrid subjectivity is played out in a difrasismo of difrasismos. This broad cultural difrasismo seems to me to characterize the Chicano subject. Not only does it yoke together different elements, it keeps present the separate elements and the new concept it creates" (18).

But when it comes to actually representing the manner in which Chicano poetry plays out a "difrasismo of difrasismos", Arteaga refers to linguistic hybridity as the best way to encapsulate Chicano's hybrid subjectivities: 
Linguistically, Chicano poetry often manifests some degree of interlingualism, employing English, Spanish, caló (Chicano slang), and perhaps Nahuatl. In this way, the poems work out linguistically with thought what the border does culturally with the nation and what mestizaje does racially with the body. [...] hybridity is the mode of both Chicano poem and Chicano subject. (10)

Although it is obvious that the linguistic form of any text may well be considered as its most outstanding feature, at least inasmuch as the language or languages a text is written in is quite a noticeable characteristic, it is also true that no poetics may exclusively reside on one single aspect. That is the reason why my aim in this paper is to further examine the nature of half-bred poetics by analysing other formal idiosyncrasies of Chicano literature which are not as amply explored as that of its interlingualism and code-switching. Whatever those features are, however, they should somehow reflect a vision of the Chicano subject in keeping with Anzaldúa's definition of the Chicano borderlands which I quoted at the beginning of this paper, the one that represented the border as that territory built out of paradoxes and ironic discrepancies.

Not surprisingly, then, paradox and irony are basic constituents of Chicano literature. They are common rhetorical figures in many other literary traditions as well, but they serve a specific purpose in border literatures: both are used as yet another manner to express, at the formal level, the hybrid nature of the border subject. Besides, many "half-bred" writers resort to them in order to find a unifying trope that focuses the reader's attention on the issue of identity problems. Despite this similarity, however, the use of paradox and irony in border literatures shows a different distribution which depends on the kind of literary genre one is dealing with. Thus, whereas poetry frequently turns to paradox in order to poetically express the apparent contradictions of a hybrid identity, the short story, as I will show later on, abounds in situations which underline the kind of "discrepancy" that we associate with dramatic irony, that is, the disagreement "between what a character believes or says and what the reader or audience member knows to be true" ("Irony", Bedford/St. Martin's).

The sometimes concise, abstract and polysemous nature of poetry makes it prone to use a rhetorical figure such as paradox: a few concepts evoke "an apparently self-contradictory (even absurd) statement which, on closer inspection, is found to contain a truth reconciling the conflicting opposites" (Cuddon 1999: 634). Many Chicano poems exemplify this treatment of paradox as the text's unifying trope. Pat Mora's "Legal Alien" (1990), for example, centres on its paradoxical title and each of its lines keeps on adding paradoxes to it, the aim being to define that elusive Chicano/a subject who is "an American to Mexicans / a Mexican to Americans". Gloria Anzaldúa resorts to much the same strategy in "To Live in the Borderlands Means You" (1987). Here the persona defines the Chicano borderlands in utterly confounding terms: "enemies are kin to each other", "you are at home, a stranger". And if we go a few years back in time to that most classical of Chicano poems, Rodolfo Gonzales's "Yo soy Joaquín" (1967), we find exactly the same need to characterize Joaquín, the Chicano Everyman, in a twofold baffling contradiction which rounds up the text: "My blood is pure / I am Aztec Prince and Christian Christ". Examples such as these are countless, but my aim in this paper is not to dwell on poetry, so those few cases should suffice to prove my point. 
What interests me here, though, is the analysis of whether Chicano/a short fiction writers have also seen the need to make their texts revolve around a unifying trope in the same way that many poets have. The length of this paper does not allow me to deal with a large number of examples, but at least I am going to analyse four short stories which may be representative of other texts, both formally and thematically, and which will show that, very frequently, fiction writers actually resort to dramatic irony, in particular, as that rhetorical axis on which everything in their texts rotates. The narrative nature of short fiction, a feature that may not necessarily be present in poetry, makes dramatic irony a figure particularly appropriate for that genre, inasmuch as it requires the existence of characters (some of which may have more information than others, or less than the reader), the building up of dramatic situations and events, etc., all of which are constituent elements of the short story.

Denise Chávez's title story of The Last of the Menu Girls (1986) may well be used as an example of the point I am trying to make. The main character in this story, Rocío Esquivel, identifies herself with the portrait of a nurse which is hung in the hospital where she works as a "menu girl". At the beginning of the story, we hear her saying: "I saw myself in her, helping all of mankind" (2349). She does not know who that woman is, but other characters do know her identity and will later on inform Rocío of it. The picture actually represents Florence Nightingale, who has been considered as "the embodiment of the nursing profession, but also of white and, more specifically, Anglo-Saxon womanhood" (Anderson 2000: 246). Even after knowing who the white nurse is, Rocío will admit that there are some similarities between Florence Nightingale and herself ("Maybe the hair" [2353], she says to her friend Arlene). However, Rocío can never really be Florence Nightingale because "her ethnicity and brown skin identifly her with the abject body" (Anderson 2000: 246); so, by “[r] ecognizing herself in Florence Nightingale, Rocío misrecognizes herself” (246).

This misrecognition on her part is an example of dramatic irony and of how this trope is used in a Chicano short story to embody some of the identity problems that border subjects may suffer from. Here the discrepancy that is associated with that kind of irony takes place between, on the one hand, Rocío's desire to be a model nurse whose deeds have made it into history books and whose portrait is hung on the walls of institutions throughout the world, and, on the other, Rocío's reality: her belonging to an ethnic group which is mainly made up of abject bodies, those of the wetbacks who cross the Río Grande (like Juan María the Nose) or those of the nurses who, like her, are there "to clean up the mess" (2358), in the words of Esperanza González, the head surgical floor nurse. Rocío seems to believe that she can become anyone she wishes to, but the reader of this story cannot help realizing her intimate connection with abjection. Despite the title's pomposity in its reference to Rocío's job at Altavista Memorial Hospital, she will not go down into history books for performing any great deeds in a famous war. Actually, her role as a menu girl who fills in forms with the patients' preferences for their daily menus will certainly pass unnoticed by everyone, with the exception, perhaps, of the abject bodies she waits on.

Esperanza González is another character who further contributes to the impact of the discrepancy observed in Rocío's characterization between what she herself believes and says and what the readers perceive. Esperanza's name is itself ironic, although in this case what we find is verbal irony, since this nurse is a "Esperanza of no esperanzas" (2358). Dramatic irony appears when we read that Nurse González, who is constantly complaining 
about the wetbacks who keep coming to the US and causing "messes" which she is to clean up, is, in fact "dark and squat, pura india tortured by her very face" (2359). Like Rocío, she lacks self-knowledge or misrecognizes herself. In any case, she has a self-perception which is shared by neither the other characters in the story nor the reading public. She is unable to identify herself as having any connections with Juan María, the story's wetback; yet, the narrator (Rocío) and the readers know she is "pura india", that is, another antithesis of Florence Nightingale.

This is then the crux of the text: the abject bodies seem unable to see themselves immersed in their abjection, incapable of admitting that the US social, cultural and economic systems have put them in an inferior position from which, despite American myths of equality, not everyone can rise. Other characters and the reading public, however, can clearly discern the dramatic irony inherent in Rocío's and Esperanza's misperceptions and faulty visions.

Sandra Cisneros' "Mericans" (1991) is the second text I would like to comment on. Its title makes us think of Anzaldúa's "third country" once more, since the term "Mericans" is neither "Mexicans" nor "Americans", yet contains elements of both. As in Chávez's "The Last of the Menu Girls", here dramatic irony is present from the very title of the story, although the reader will not perceive it as such until the end. Cisneros tells the story of three Chicano children, a couple of boys (Alfredito/Junior and Enrique/Keeks) and their sister Micaela/Michele, who are spending some time with their grandmother outside the church where the image of la Virgen the Guadalupe is kept, in Mexico D.C. Throughout the text there is a dramatization of the problems of Micaela/Michele to find the place where she belongs. She is first shown playing with her brothers in the plaza right outside the church; the boys insult her by calling her "Girl" (18) and refuse to allow her to take part in their games. In this way, the public sphere is characterised as being dominated by the males, and therefore not appropriate for her. She then enters the church, which she finds stinking and constraining, only to realize that she does not belong there either, even though this space is highly influenced by the presence of both the Virgin and her grandmother, two strong female figures. Micaela/Michele, the Chicana who is ill at ease in both the patriarchal public sphere and the traditional female spaces, must go on looking for her place.

In her third and final search she decides to go back to the plaza where she had left her brothers. This is the last part of the story; however, Micaela/Michele will not find here what she is in need of. If the first and second searches showed her that she still has much to do as far as the formation of her gender identity is concerned, in the sense that she will have to start by making up her mind about the kinds of public and private spaces she wants to inhabit, the story's coda shows to her the immensity of yet another front in the process of identity formation: the issue of national identity, which in the case of the protagonists is neither fully "Mexican" nor "American". Besides, their identity is yet to be accepted by Mexicans, here represented by their grandmother, who diminishes the US for being a "barbaric country with its barbarian ways" (19) where Mexicans forget to go to church and pray. The story's finale puts the emphasis on the fact that that new identity is also unacknowledged by the American status quo, impersonated in the story's third part by an American lady who offers Alfredo/Junior some chewing-gum "in a Spanish too big for her mouth" and then asks him if she can take "un foto" (20) of him, which shows her intention 
to take picturesque photographs of an "authentic" Mexican boy back home and keep them as souvenirs of her immersion into what she considers "real" Mexican life, as mementoes of her interplay with "real" Mexican people during her vacation.

Soon after the boy gets hold of the chewing-gum, he addresses his brother and sister, who has just come out of the church, and offers them some Chiclets in standard American English. The lady is then greatly surprised to see that they all speak English, which Alfredo/ Keeks explains by stating, with absolute aplomb, "we're Mericans" (20). The new term he uses to refer to heir national identity is wonderfully polysemous. On the one hand, we should take into account that he is chewing and therefore the term may simply represent a mispronunciation on a child's part. The fact that he is a Chicano, on the other, and also that he is neither recognized by his Mexican grandmother as Mexican nor by the American lady as American, would explain the reason why the writer has seen the need to invent a term for this new identity construct.

In any case, this concluding section offers us one more case of how a short story writer has used dramatic irony to focus the reader's attention on the story's main conflict, that of the controversial nature of border identity. In this particular instance, the discrepancy is seen between what a character, the American lady, thinks (that the boy whom she has given chewing-gum will make a wonderful souvenir of "real" Mexico) and what the reader and the children themselves know: that they are compatriots of the myopic American lady, even if their national identity is not delineated on the same basis as her own is.

My third example of how Chicano/a writers of short stories use dramatic irony is found in Roberta Fernández's "Double Talk" (1993). Originally, this story consisted of nine sections, some of which were written in Spanish, while others were in English with instances of code-switching into Spanish. (However, when it was published in New Chicana/Chicano Writing 3, the Spanish sections and the phrases written in Spanish that appear in the English ones were all followed by a translation into English.) Spanish is used in sections I, II, III, V, VI and VIII, all of which focus on Juan Pérez, a Mexican man who illegally crosses the Mexican border so as to get to the USA. Whenever the narrator is centred on Juan, the Spanish language is used as the communication means, regardless of the setting of the action, which is Mexico in section I, II and III, and the US in sections V, VI and VIII. English, by contrast, is employed when the narrator is focusing on a few old ladies of Mexican origin who are legal residents in the US. Among them we find Doña Flora, Doña Eloísa, Doña Rosa, and Doña Milagros.

This distribution in the use of Spanish and English is perhaps one of the instances of dramatic irony which are most rapidly perceived in this short story. The text makes it clear to the reader that both the characters who live north of the border and those who live south of it speak Spanish (even the American policemen do!). Yet, the narrator turns to Spanish when dealing with an illegal immigrant such as Juan, but resorts to English in order to tell the events that are related to legal characters such as the above-mentioned old ladies. English is then the language associated with anything good (American affluence, legal immigrants, law and order, respectful old ladies, etc), whereas Spanish is in connection with whatever instances of evil one may think of: crime, illegal immigration or young and uncontrollable gang members, among others. Thus, the first time we hear of Juan Pérez we are told in Spanish that the squad is after him: "Aquel jueves todos pronto supieron lo que no debían 
saber. Juan Pérez y los otros muchachos se habían ido desde la madrugada cuando primero había corrido la noticia de que pronto iban a venir por ellos" (30). The first description of the old ladies, however, is done in English; they are presented as victims, whereas recent immigrants such as Juan Pérez are criminalized:

As the men had slowly died off, one by one, the barrios near the international bridge had become home to old women struggling to maintain some peace of mind as crimes, unheard of in the past, suddenly began to proliferate around them. In recent years, an endless flow of transients made their way through the area, and the elderly women soon discovered that their homes had become sitting ducks for the desperate and the needy. (36-37)

At the end of the story, however, the reader is aware of the fact that these ready-made associations were wrong. It becomes obvious that there is a discrepancy between the subliminal message conveyed, among other things, by that precise distribution of English and Spanish and the actual events of the story. In short, we realise that the connection between the old ladies and goodness is false, just as the association of recent immigration with crime is unsustainable. Doña Milagros, for instance, who was always frightened of recent illegal immigrants who might make her a victim of their crimes, is in fact a drug dealer who moved to the US only a few months before the main events narrated in the story take place. All her apparently charming elderly neighbours, who are likewise terrified of the new immigrants, have forgotten that they are immigrants themselves, if only of previous immigration waves. They fear they might be attacked by those young boys who pass over the same border they themselves crossed years ago, but the reader is informed of the fact that most of the illegal immigrants who are caught are apprehended by the immigration authorities, not by the police. Doña Milagros, on the contrary, will be arrested by the police and sent back to Mexico. Juan, for his part, manages to avoid both "la migra" and the police and the reader is left with the feeling that, given the right circumstances, his good nature will allow him to contribute a great deal to his foster country.

Juan Pérez is, in fact, the man who helps Doña Milagros. He had sought refuge in her house after he had seen her leave for Doña Flora's. While he was at Doña Milagros', a couple of robbers entered the house and he knocked them down, thus preventing them from stealing anything from the old lady. By the time the police got to Doña Milagros', Juan had already left, but the two robbers were still there, their conscience not yet regained. The police officers' explanation to Doña Milagros that it "Looks like gang members fought against each other in your house" (44) is certainly ironic for the reader who does know the truth. Besides, as representatives of the status quo, the police are expected to tell the right version. Consequently, it is doubly ironic to see that they hardly know anything: they ignore the fact that Doña Milagros is not a victim, but a criminal herself, despite her elderly charm, and they are similarly unconscious of the fact that an illegal immigrant, one of those young boys everyone north of the border is so afraid of, is responsible for knocking down the robbers.

Newspapers, which are likewise expected to tell the truth, are similarly mistaken in their conclusions. They constantly insist on criminalizing the recently-arrived: "the paper had warned against a band of teen-age Ilegales who were creating havoc everywhere they 
appeared" (39). For this reason, when it is time to report the incidents that have taken place in Doña Milagros' house, they wrongly state that "the gang of illegal hoodlums had started a gang war, making them more unpredictable and more dangerous than before" (45). And they do so once and again ("The News was repeated hourly on the TV and the radio" [45-46]), thus amplifying the impact of this other case of dramatic irony where only the reader knows the whole truth about the police's and the papers' biased stories, Doña Milagros' criminal doings and Juan Pérez's innate sense of justice.

The fourth and final example of how dramatic irony may be used in a Chicano short story is Daniel Chacón's "Godoy Lives" (2000). Chronologically speaking, this is the most recent short story I have selected for my analysis. But the actual reason why it comes last is that this is perhaps the text where dramatic irony is most exhaustively employed, where the discrepancy between what some characters believe and what the reader knows is most radically shown. "Godoy Lives" tells the story of a twenty-four year old Mexican called Juan, married to María and father of four-year-old Juan Jr. Due to his family's economic hardship, Juan sees the need to go to the US. He decides to cross the border by showing the immigration authorities a green card that belonged to a deceased guy called Miguel Valencia Godoy. At the border, he chooses a line at the beginning of which there is a white INS officer. But when he is two people from the front, a tall Chicano officer takes the white man's place. Juan is afraid of Chicano officers because people he knew had told him that "the worst immigration officers in the U.S. were the ones of Mexican descent" (6). When it is his turn to be interviewed, Juan is terrified that he is going to be found out. Despite his fear, though, and his problems to answer the Chicano officer's questions not as himself but as Miguel Valencia Godoy, he manages to come through the examination: the officer, Francisco Pancho Montes Godoy, turns out to be the deceased man's cousin and does not recognize Juan as an impostor. On the spur of the moment Pancho decides to become Juan/ Miguel's mentor in the US, to take him to his own house and to find a good wife for him.

From that moment onwards, Juan is immersed in a world of lies that grow more and more complex as the plot advances. His nervous system is about to collapse on several occasions when he is afraid that his performance might be discovered. But he always succeeds in fooling the people he comes in contact with. And not only that: Juan/Miguel gets a very good job at a ranch and falls in love with Elida, Pancho's sister-in-law; in other words, he finally acquires both material and emotional success. Up until this point, Juan has been lying to others about his real identity, but he seems to have been sure of who he really was and the reasons why he was there: to make as much money as possible so as to send it back to Mexico and help his dear wife and son. The moment he falls in love, though, there is a turning point in his mind. He is no longer certain that his wife has ever loved him ("She hadn't even cried when he left. She was probably glad he was gone" [15]), although a few months before he had thought she was "the greatest" (9). Besides, the keeping up of appearances gradually stops being a nuisance for him; actually, he seems to have internalised the values, customs and goals that Pancho has set for him to such an extent that he enjoys the situation and considers the possibility of adhering to that new role of his "maybe forever" (15).

But before Juan can discard his old self once and for all, he is yet to pass the definitive trial. This takes place when he is informed that Pancho has gone to the bus station to pick 
up Miguel Godoy's widowed mother so that she can live with her only living son. He also learns that Godoy's father has bequeathed his son such a big amount of money that he will never have to work again if he does not want to. At this stage, both Juan and the reader are very tense, the same as when he was interviewed at the border, or when another Chicano realised that Juan's accent did not sound as the Spanish of someone from Jalisco, Miguel Godoy's place of origin, or on all the other occasions when his real identity was about to be uncovered. However, this time things are even worse. It is precisely now that he is a rich heir, as well as a legal resident and a man in love, that an eventual discovery might hurt him most.

The actual encounter between Juan and his new mother does not take place within the story's boundaries, so the outcome of this situation is for the reader to imagine. However, there are two elements in the story that allow us to construct it as a successful one. First, the fact that, before he goes out into the living room to meet his new mother, Juan looks at himself in the mirror and, as he stares at his reflection, he sees "Miguel Valencia Godoy. Clean-shaven, handsome, lean-bodied, confident" (19). For a moment, his eyes still reflect Juan's insecurity, but he quickly shakes that off and then proceeds into the living room. Secondly, Juan knows that his new mother is very senile: "She forgets things sometimes. People sometimes" (18). Both the old woman's senility and his own self-assurance will probably help him pass as Miguel Godoy at the most difficult test of all.

The whole story is then a perfect exemplification of dramatic irony: all throughout it the reader knows that Juan is not the person everyone takes him for, but the rest of the characters involved in the action are fooled into thinking he is Miguel Godoy. At the end of the story, when Juan looks at himself in the mirror and sees Miguel Godoy instead, even Juan seems to have been deceived, so that now it is only the reader that knows the whole truth. Juan is an insecure man who could not even take control of the situation when he was courting María. During the first stages of his stay in the US he is really an illegal immigrant who values his family above all other things and for whom money is important only inasmuch as it allows people to lead a comfortable life. His stay in the US finally transforms him into someone completely different: Miguel, a green-card holder who loses his Mexican values while acquiring the American principles of materialism and individualism.

Dramatic irony is thus employed here to convey the idea that the Chicano subject is a very complex one, one whose identity cannot be easily predicted and should be under no circumstances defined in terms of his/her papers. In the case of Juan, we see that another Chicano, his newly acquired cousin Pancho, takes it for granted that, since Juan/Miguel is a green-card holder, he is above the wetbacks he so intensely despises; also, Juan/Miguel's legal status allows him to be accepted as a member of Pancho's family and makes him desirable as both a husband for Elida and a partner for Pancho in an investment the INS officer is planning to do. Juan himself, but without his stolen green card, would have been immediately expelled from the US and considered by Pancho as mere scum. For the reader, it is ironic to see that the more successful someone is, at least at the level of appearances, the better that person is treated. And it is doubly ironic to notice that for those people who make it, it is very easy to forget those who have been left behind. And even worse: to construct the others as undeserving of their loyalty. 
All these four stories considered, it is now time to round up my analysis by pointing out a few concluding remarks. Taking into account that border identity is a very important theme in Chicano literature and also that tropes are generally used to highlight outstanding elements in a text, it is only natural that Chicano writers should resort to specific literary figures so as to help their readers focus their attention on precisely the problematic constructions of border identity. Given that, as Anzaldúa's definition showed, border identities seem to come out of paradoxical formations, it is in a way predictable that poetry should primarily resort to paradox itself as the unifying trope that underlines the poet's concern with identity problems. Short stories, on the other hand, prefer dramatic irony, a figure which is also based on a discrepancy, but which is more appropriate for a narrative genre.

In this paper I have analysed several texts where dramatic irony is used as the main literary figure. The interesting thing for me now is to point out that they are representative of a number of possibilities which the writer may have at hand. First, in "The Last of the Menu Girls" we recognise a discrepancy between what some Chicanas believe about themselves and what the reader/other characters perceive. Therefore, we find a case of wrong selfperception on the part of some Chicana characters. "Mericans", on the other hand, shows Mexicans' and Americans' wrong perception of Chicanos/as. Mexicans (represented by the grandmother) see them as degenerated and corrupt, whereas Americans (embodied by the American lady) see them as tokens of an exotic culture. This is not a case of Chicanas' wrong self-perception, as in "The Last of the Menu Girls", but of wrong perception of Chicanos/as on the part of both Mexicans and Americans.

In "Double Talk" there is yet another instance of a slightly different use of dramatic irony. Here we discover a discrepancy between what the reader and Juan Pérez know and what the old ladies, the police and the papers say. In other words, this story shows legal Chicanos/as' wrong perception of illegal and more recently arrived Chicanos/as. "Godoy Lives", for its own part, elaborates further into that same kind of misperception by calling attention to the fact that possession of money and certain documents do change the way in which Chicanos/as are judged. Ironically, the respect of one's own identity does not seem to pay as well as the adherence to a newly acquired identity according to which personal fulfilment is based on the accumulation of wealth and family duties are replaced with absolute individualism.

The complexities of the identities that come to the surface in the Chicano borderlands is such that no one seems to be sure what they really are like. "The Last of the Menu Girls" shows us that the subjects involved in those processes of identity formation may misrecognise themselves. Those north and south of the US-Mexican border are likewise puzzled by these new identities, as the story "Mericans" proves. Finally, "Double Talk" and "Godoy Lives" evidence that Chicanos/as who are now legal residents in the US may fall prey to the same prejudices that were previously applied to them by the American status quo by wrongly perceiving the illegal or newly-arrived immigrants as dangerous. In any case, though, dramatic irony is in all those texts used to make us aware of the danger of monolithic and prescriptive ideas about gender and national identities. It demonstrates that all visions may be faulty, all eyes myopic. Rocío's wishful perception of herself as a great nurse makes the reader smile about the unattainability of her dreams, just as the final me- 
tamorphosis of Juan's insecure stare into Miguel Godoy's confident look does not prevent us from forgetting his wife's plight as a lonely mother left behind in Mexico.

\section{REFERENCES}

Anderson, D. 2000. "Displaced Abjection and States of Grace: Denise Chávez's The Last of the Menu Girls". American Women Short Story Writers. A Collection of Critical Essays. Ed. J. Brown. New York: Garland Publishing. 235-250.

AnzaldúA, G. 1987. Borderlands/La Frontera: The New Mestiza. San Francisco: Aunties Lute Books.

Arteaga, A. 1997. Chicano Poetics. Heterotexts and Hybridities. Cambridge: Cambridge University Press.

BedFord/ST. MARTIN's. "Irony". Glossary of Literary Terms. http://www. bedfordstmartins.com/literature/bedlit/glossary_f.htm (26 September 2007).

Chacón, D. 2000. "Godoy Lives”. Chicano Chicanery. Houston, TX: Arte Público Press. 5-19.

ChÁvez, D. 1986. "The Last of the Menu Girls". The Norton Anthology of American Literature. Vol. 2. Eds. N. BAYM et al. 2346-2363.

Cisneros, S. 1991. "Mericans". Woman Hollering Creek and Other Stories. New York: Vintage. 17-20.

Cuddon, J.A. 1999. The Penguin Dictionary of Literary Terms and Literary Theory. 4th ed. Harmondsworth: Penguin.

Fernández, R. 1993. "Double Talk”. New Chicana/Chicano Writing 3. Ed. C.M. Tatum. Tucson and London: The University of Arizona Press. 30-46.

GonZÁLes, R. 1967. "Yo soy Joaquín”. http://www.judybaca.com/dia/text/joaquin.html (26 September 2007).

Mora, P. 1990 (1984). "Legal Alien”. Making Face, Making Soul/Haciendo Caras. Creative and Critical Perspectives by Feminists of Color. Ed. G. AnzaldúA. San Francisco: Aunt Lute Books. 1990. 376.

WAH, F. 1997. "Half-Bred Poetics". Absinthe 9, 2. 60-65. 